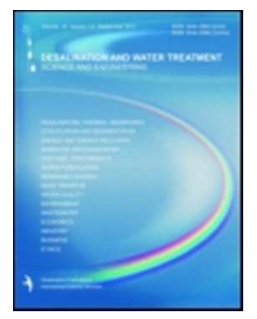

\title{
Synthesis of nanostructured ZnO/copper electrodes for nitrate electroreduction
}

\begin{tabular}{|r|l|}
\hline Journal: & Desalination and Water Treatment \\
\hline Manuscript ID & Draft \\
\hline Manuscript Type: & Original Paper \\
\hline Date Submitted by the Author: & n/a \\
\hline Complete List of Authors: & $\begin{array}{l}\text { Ait Ahmed, Nadia; Laboratoire d'Electrochimie, de Corrosion et de } \\
\text { Valorisation Energétique(LECVE), Université de Bejaia, 06000 Bejaia, } \\
\text { Algérie. } \\
\text { Hammache, Houa; Laboratoire d'Electrochimie, de Corrosion et de } \\
\text { Valorisation Energétique(LECVE), Université de Bejaia, 06000 Bejaia, } \\
\text { Algérie. } \\
\text { Eyraud, Marielle; Aix-Marseille Univ, CNRS, MADIREL UMR 7246, équipe } \\
\text { Electrochimie des Matériaux, 13397 Marseille Cedex 20, France. } \\
\text { Makhloufi, Laid; Laboratoire d'Electrochimie, de Corrosion et de } \\
\text { Valorisation Energétique(LECVE), Université de Bejaia, 06000 Bejaia, } \\
\text { Algérie. } \\
\text { Gabouze, Noureddine; Centre de Recherche en Technologie des } \\
\text { Semiconducteurs pour l'Energétique (CRTSE), 2, bvd. Frantz Fanon, B.P. } \\
\text { 140 Alger 7 Merveilles, Alger, Algérie. }\end{array}$ \\
\hline Keywords: & \begin{tabular}{l} 
ZnO, Electrodeposition, Copper, Electrocatalysis, Nitrate reduction \\
\hline
\end{tabular} \\
\hline
\end{tabular}

\section{SCHOLARONE \\ Manuscripts}




\title{
Synthesis of nanostructured $\mathrm{ZnO}$ /copper electrodes for nitrate
}

\section{electroreduction}

\author{
N. Ait Ahmed ${ }^{1}$, H. Hammache ${ }^{1}$, M. Eyraud ${ }^{2}$, L. Makhloufi ${ }^{1}$, N. Gabouze ${ }^{3}$ \\ ${ }^{1}$ Laboratoire d'Electrochimie, de Corrosion et de Valorisation Energétique(LECVE), Université de \\ Bejaia, 06000 Bejaia, Algérie. \\ ${ }^{2}$ Aix-Marseille Univ, CNRS, MADIREL UMR 7246, équipe Electrochimie des Matériaux, 13397 \\ Marseille Cedex 20, France. \\ ${ }^{3}$ Centre de Recherche en Technologie des Semiconducteurs pour l'Energétique (CRTSE), 2, bvd. \\ Frantz Fanon, B.P. 140 Alger 7 Merveilles, Alger, Algérie.
}

\begin{abstract}
In this work, $\mathrm{ZnO}$ thin films were synthesized on the surface of copper electrodes by an electrochemical method at different deposition potentials - $-0.6,-0.8,-1$ and $-1,2 \mathrm{~V}$ versus SCE. The as-prepared $\mathrm{ZnO}$ modified $\mathrm{Cu}$ electrodes $(\mathrm{ZnO} / \mathrm{Cu})$ have been employed for electrocatalytic nitrate reduction under neutral $\mathrm{pH}(\mathrm{pH}=6.8)$ condition in $0.1 \mathrm{M} \mathrm{KNO}_{3}$ using cyclic voltammetry and amperometry techniques. The electrode surface and structure were investigated by scanning electron microscopy (SEM) and X-ray diffraction (XRD) techniques. The effects of the electrodeposition potential and time on the morphology, structure and electrocatalytic properties were studied. The results show that under optimized $\mathrm{ZnO}$ electrodeposition conditions, the $\mathrm{ZnO} / \mathrm{Cu}$ electrode exhibits interesting electrocatalytic performance in nitrate reduction. A well defined and reproducible peak with maximum current density was obtained for $\mathrm{ZnO} / \mathrm{Cu}$ electrode elaborated at $-1 \mathrm{~V}$ for $20 \mathrm{~min}$ electrodeposition time. Kinetic study by chronoamperometry is indicative of ammonia formation.
\end{abstract}

Keywords: ZnO; Electrodeposition; Copper; Electrocatalysis; Nitrate reduction

\section{INTRODUCTION}

Nitrate reduction and determination is extremely important for environment and public health issues. The development of specific analytical methods for the detection and destruction of nitrate is of great importance to limit pollution of the natural environment. Many methods are used to remove $\mathrm{NO}_{3}{ }^{-}$ions from contaminated water, such as reverse osmosis, photocatalytic, biochemical, chemical and electrochemical reduction [1-4]. Most of them involving complicated and time-consuming procedures. In contrast, electrochemical nitrate treatment 
can offer a promising and attractive solution due to its advantages regarding low cost effectiveness, convenience, ability to treat highly concentrated nitrate effluents and environmental friendliness $[\mathbf{5 , 6 ]}$.

As the products of the nitrate electroreduction are critically dependent on the nature of the cathode material [7, 8], several simple metal electrodes (Nickel, Platinum, Graphite, Glassy carbon, Copper, etc.) have been widely used for the reduction of nitrate [9-14]. Compared to other materials, $\mathrm{Cu}$ metal has shown good catalytic character for nitrate reduction [15-17]. However, the use of bare electrodes for the reduction of nitrate requires high potentials [18, 19] and these electrodes tend to be poisoned by the species formed during the electrochemical process [20]. This considerable drawback limits their use for large scale applications. A good way of lowering the reduction potential and limiting surface poisoning is the use of modified electrodes and their application has received considerable attention in recent years due to many advantages, such as wider operational potential window, easy manufacture, low price, renewable surface and longer life time [21-23]. In the other hand, $\mathrm{ZnO}$ are the object of quickly growing in the last few years, due to its number of exciting properties [24-26]. It is a wide band gap semiconductor material with $\mathrm{Eg} \approx 3.3 \mathrm{eV}$ and large excitonic binding energy of $\sim 60 \mathrm{meV}$ [27]. Also, it's an environmentally friendly material that does not form toxic byproducts [28], with low price, high chemical and thermal stability. Due to these excellent properties, $\mathrm{ZnO}$ nanomaterials have been used as efficient electron mediators for the fabrication of electrochemical sensors. The electrochemical reduction of nitrate ions has been investigated over a large number of modified electrodes, for example, metals modified electrode [29, 30] and polymer modified electrode [31]. To our knowledge, fewer research articles have been published on electrocatalytic activity of $\mathrm{ZnO}$ toward nitrate reduction.

The main objective of the present study is to elaborate $\mathrm{ZnO}$ modified copper electrode by electrodeposition method and we have reported the applicability of a $\mathrm{ZnO} / \mathrm{Cu}$ electrode for the selective reduction of $\mathrm{NO}_{3}{ }^{-}$under neutral $\mathrm{pH}$ condition. The electrocatalytic activity of the asprepared $\mathrm{Cu}-\mathrm{ZnO}$ electrode is compared with that of a pure $\mathrm{Cu}$ surface.

The electrocatalytic ability of $\mathrm{ZnO} / \mathrm{Cu}$ was thoroughly investigated by cyclic voltammetry (CV) and chronoamperometry.

\section{Materials and methods}

\subsection{Reagents and solutions}

All chemicals were of analytical-reagent grade from Merck or Fluka and were used directly without further purification. All aqueous solutions were prepared with bi-distilled water 
(presenting high resistance $\sim 18 \mathrm{M} \Omega$ ). The supporting electrolyte used in all the experiments was $0.1 \mathrm{M} \mathrm{KNO}_{3}$ or $0.1 \mathrm{M}$ phosphate buffer solutions.

\subsection{Apparatus}

All the electrochemical experiments were carried out using a potentiostat/galvanostat (Autolab PGSTAT30) coupled with HP computer under "Voltamaster logitiel". The electrochemical cell was assembled with a conventional three-electrode system: a bare $\mathrm{Cu}$ or $\mathrm{ZnO} / \mathrm{Cu}$ were employed as working electrodes. Platinum wire is used as auxiliary electrode and a saturated calomel electrode (SCE) as reference.

The surface morphology of the modified electrode was investigated by a scanning electron microscope (SEM) (Hitachi, S-570). The Si-Li electrode was used for light elements with a $133 \mathrm{eV}$ resolution at low counting rate and beam parameters of $20 \mathrm{keV}$ and $160 \mathrm{pA}$. X-ray diffraction (XRD) analyses were performed on a Siemens D5000 diffractometer using filtered $\mathrm{CuK} \alpha(\lambda=0.15406 \mathrm{~nm})$ as a radiation source. The diffractometer was operated at $40 \mathrm{kV}$, room temperature, with a scanning rate of $10 \mathrm{~min}^{-1}$.

\subsection{Preparation of the synthesized $\mathrm{ZnO} / \mathrm{Cu}$ electrode}

A wet electrochemical method was employed for the synthesis of $\mathrm{ZnO}$ thin film.

$\mathrm{ZnO}$ thin films were deposited from an electrolyte containing 5. $10^{-3} \mathrm{M} \mathrm{Zn}\left(\mathrm{NO}_{3}\right)_{2}, 6 \mathrm{H}_{2} \mathrm{O}$ and $0.1 \mathrm{M} \mathrm{KNO}_{3}$ at $70^{\circ} \mathrm{C}$ using a different potentials $-0.6,-0.8,-1$ and $-1.2 \mathrm{~V} / \mathrm{SCE}$ and at different deposition times 5, 10, 15, 20, 25 and $30 \mathrm{~min}$. The $\mathrm{pH}$ of solution is fixed at 6 .

Before the electrodeposition process, the massive $\mathrm{Cu}$ were polished using emery paper with 1200 grit, degreased with acetone, cleaned with twice distilled water and dried with a soft tissue paper. This $\mathrm{Cu}$ electrode was then used as the working electrode in the electrodeposition of $\mathrm{ZnO}$ on a copper electrode.

\section{RESULTS AND DISCUSSION}

\subsection{Electrochemical study by cyclic voltamperommetry and chronoamperometry}

Prior to the development of $\mathrm{ZnO}$ by chronoamperometry, we found it useful to consider the voltammetric behavior of $\mathrm{ZnO}$ deposit. The cyclic voltammetry study was performed in a potential range of - 0.5 to $-1.6 \mathrm{~V}$ versus SCE onto copper substrate. The potential scan was initiated in the negative direction from the open circuit potential (OCP) at a scan rate of 8 $\mathrm{mVs}^{-1}$ (Fig. 1). As stated in our previous works [25], the $\mathrm{ZnO}$ reaction formation is initiated by the nitrate reduction reaction. We can see in Fig. 1 that the current begins to increase for a potential of $-0.2 \mathrm{~V}$ indicating that the reaction of nitrate reduction on the copper substrate is 
very active leading to $\mathrm{ZnO}$ deposit at very low cathodic potentials. Below $-0.6 \mathrm{~V}$, the cathode current increases faster with the potential increase indicating the activation of the $\mathrm{ZnO}$ formation process. However, the rapid increase in intensity at $-1.25 \mathrm{~V}$ corresponds to the water reduction reaction. No anodic peak appears in the return sweep, indicating that no zinc metal is codeposited with $\mathrm{ZnO}$.

Accordingly to the voltammetric study, $\mathrm{ZnO}$ may be deposited at low cathodic potential as $0.2 \mathrm{~V}$ and high deposition rate will be reached for a potential values more cathodic than -0.6 $\mathrm{V}$; thus a large potential window from $-0.6 \mathrm{~V}$ to $-1.2 \mathrm{~V}$ versus SCE was chosen to deposit $\mathrm{ZnO}$ thin films on $\mathrm{Cu}$ substrate using chronoamperometry, in solution containing $5 \mathrm{mM}$ of $\mathrm{Zn}$ $\left(\mathrm{NO}_{3}\right)_{2}$ and $0.1 \mathrm{M} \mathrm{KNO}_{3}$. The applied potentials correspond to the maximum peak for $\mathrm{ZnO}$ deposit, readings from the previous figure. The obtained current transients curves are illustrated in Fig.2. We can see that after an initial sharp peak the current decreases rapidly in the first few seconds due to the charge of the double layer which can be accompanied by the adsorption of $\mathrm{ZnO}$ at the interface. After this, the current stabilize to form a plateau corresponding to the stability of $\mathrm{ZnO}$. Also, we can see that an increase in cathodic potential was accompanied by an increase in cathodic plateau. It is worth noting that increasing applied potential leads to the increase in zinc oxide deposition current densities.

\subsection{Morphological and structural properties of the synthesized $\mathrm{ZnO}$ thin films}

The SEM micrographs and the XRD spectra for a selected $\mathrm{ZnO} / \mathrm{Cu}$ electrodes synthesized at 20 min electrodeposition time are shown in Fig. 3 and 4. It can be noted that, the morphology of the surface of $\mathrm{ZnO}$ deposited at $-0.6 \mathrm{~V}$ (Fig.3 (a)) reveals the grains structure, with an inhomogeneous distribution. Increasing the potential at $-0.8 \mathrm{~V}(\mathbf{F i g . 3}(\mathbf{b}))$, the deposit becomes more compact, homogeneous and the surface is made from hexagonal shapes stems. For more cathodic potentials as $-1 \mathrm{~V}$ and $-1.2 \mathrm{~V}$ (Fig. 3(c and d)), the morphology of the $\mathrm{ZnO}$ modified electrode is in the form of flowers oriented on the substrates surface and each flower consists of petals. $\mathrm{ZnO}$ nanoflowers will offer large surface area and expected to enhance electrocatlytic activity.

The XRD measurements confirm the formation of $\mathrm{ZnO}$ thin films on $\mathrm{Cu}$ substrate (Fig. 4). Three pronounced peaks are observed in the as-prepared samples, which can be indexed to the (100), (002), and (101) reflections of $\mathrm{ZnO}$ at $2 \theta$ value of $31.7^{\circ}, 34.4^{\circ}$ and $36.3^{\circ}$, respectively.

No other diffraction peaks were detected excluding the peaks originating from $\mathrm{ZnO}$. Although all $\mathrm{ZnO}$ diffraction peaks are in good agreement with the JCPDS card (36-1451) for a wurtzite-type $\mathrm{ZnO}$ crystal. It can be seen that, for the $\mathrm{ZnO}$ thin film electrodeposited at $-1 \mathrm{~V}$ 
for $20 \mathrm{~min}$, a significantly higher intensity of (002) diffraction peak is obtained indicating that $\mathrm{ZnO}$ flowers were preferentially oriented along the c-axis direction crystallographic face.

\subsection{Electrochemical behavior of nitrate ions at bare $\mathrm{Cu}$ and $\mathrm{ZnO} / \mathrm{Cu}$ modified electrode}

In order to evaluate the electrocatalytic behavior of the $\mathrm{ZnO} / \mathrm{Cu}$ modified electrode towards nitrate reduction, we performed voltammograms in absence of $\mathrm{NO}_{3}{ }^{-}$ions at $\mathrm{Cu}$ electrode (Fig.5 (a)) and in 0.01 $\mathrm{M} \mathrm{KNO}_{3}$ at bare $\mathrm{Cu}$ (Fig.5 (b)) and at $\mathrm{ZnO} / \mathrm{Cu}(\mathbf{F i g . 5}$ (c)) electrodes. It can be seen that, in the presence of $\mathrm{NO}_{3}{ }^{-}$, a very broad reductive wave was observed on the voltammogram recorded at $\mathrm{Cu}$ bare electrode, corresponding to the reduction of nitrates, in agreement with the results of literature [16]. For the voltammogram recorded at the $\mathrm{ZnO}$ modified electrode obtained by chronoamperometry at -1V for $20 \mathrm{~min}$, a one single, sharp and intense reduction peak appears at around $-0.7 \mathrm{~V} / \mathrm{SCE}$ (Fig.5(c)). This is the sign of increasing electrocatalytic activity on the $\mathrm{ZnO} / \mathrm{Cu}$ modified electrode. Compared to the bare $\mathrm{Cu}$ electrode, in $\mathrm{KNO}_{3}$ solution with a less intense peak reduction, we can conclude that the $\mathrm{ZnO}$ promoted the nitrates reduction. The increase in the peak current of the analytes at the surface of the $\mathrm{ZnO} / \mathrm{Cu}$ (about 2.0 times) can be explained by the increase in electronic transfer due to the increase in the surface area or to the synergic effect between $\mathrm{ZnO}$ and $\mathrm{Cu}$. Also, of one single, reduction peak is indicative a one steep reduction reaction. To $-0.8 \mathrm{~V}$ the current intensity increases and this area corresponds to the reduction of proton.

\subsection{Electrocatalytic reduction of nitrate onto $\mathrm{ZnO} / \mathrm{Cu}$ modified electrode}

It has already shown that the operating conditions have a directly effect on the morphology and properties of the deposits $[24,13]$.

In our study, we investigated the effects of electrodeposition time, bath temperature and deposition potential on the morphology and structure of the $\mathrm{ZnO}$ deposits and their possible effects on the electrocatalytic nitrate reduction.

\subsubsection{Effect of electrodeposition time and potential}

Fig.6 (a, b, c and d) shows the effect of both electrodeposition potential and time on the electrocatalytic activity of $\mathrm{ZnO} / \mathrm{Cu}$ towards nitrate reduction. Peak current of the $\mathrm{CVs}$ was increased with increasing electrodeposition time and potential, suggesting that the morphology and structure of the deposit have great influence on the electrocatalytic activity of $\mathrm{ZnO} / \mathrm{Cu}$ modified electrodes towards nitrate reduction. It can be observed that, $\mathrm{ZnO} / \mathrm{Cu}$ electrode obtained at 20 min electrodeposition time shows sharper reduction peak and higher current intensity for nitrate reduction for all potentials. 
Figure 6 (e) summarizes the effects of potential on the electrocatatlytic activity of $\mathrm{ZnO} / \mathrm{Cu}$ electrode at $20 \mathrm{~min}$ electrodeposition time. These results indicated that the electrocatalytic action was more pronounced with the $\mathrm{ZnO} / \mathrm{Cu}$ fabricated at $-1 \mathrm{~V}$. So these potential and time values were chosen as the optimums giving the best results. This increased electrocatalytic activity is probably due to the specific morphology shown by SEM analysis. In this case the $\mathrm{ZnO}$ deposit in the form of flowers is denser and covers the $\mathrm{Cu}$ substrate entirely leading to the increase in the surface area and improved mass transport. As electrodeposition time increases over $20 \mathrm{~min}$ the electrocatalytic nitrate reduction decreases probably due to the decrease of the synergetic effect between $\mathrm{ZnO}$ and $\mathrm{Cu}$ because $\mathrm{Cu}$ will be covered by more compact $\mathrm{ZnO}$ deposit. Also, the electrocatalytic nitrate reduction decreases for $\mathrm{ZnO}$ deposited at $-1.2 \mathrm{~V}$ due to poor morphology and structure because of hydrogen competing reaction.

\subsubsection{Effect of temperature}

Fig.7 shows the cyclic voltammetry of $\mathrm{ZnO}$ modified electrode deposited at $-1 \mathrm{~V}$ for $20 \mathrm{~min}$ obtained at different temperatures. As can be seen from Fig. 7, an increase in the temperature results in an increase in the intensity of the peak of nitrate reduction. The increase in the intensity of the nitrate reduction corresponds to well-ordered $\mathrm{ZnO}$ deposit. This process can be explained by more efficient conversion of $\mathrm{Zn}(\mathrm{OH})_{2}$ to $\mathrm{ZnO}$ in an ultimate step due to the temperature effect. For the rest of our study we chose a temperature of $70^{\circ} \mathrm{C}$ to make deposits.

\subsubsection{Effect of nitrate concentration}

Fig. 8 shows the voltammograms of nitrate reduction in the concentration range of $0.03-10$ $\mathrm{mM} \mathrm{KNO}_{3}$ recorded using the $\mathrm{ZnO} / \mathrm{Cu}$ electrode at a potential sweep rate of $8 \mathrm{mV} \mathrm{s}^{-1}$. We can see that the nitrate reduction peak current increases with increasing $\mathrm{NO}_{3}{ }^{-}$concentration and has a linear relationship with the concentration of $\mathrm{NO}_{3}{ }^{-}$in the considered range of concentration with a correlation coefficient of 0.9987 . The regression equations is $y=0.1374$ $\mathrm{C}_{\mathrm{NO} 3}{ }^{-}-60.3676$ with $\mathrm{R}^{2}=0.99815$. From these results, we can conclude that the $\mathrm{ZnO} / \mathrm{Cu}$ electrode can be used for nitrate electroreduction and detection.

\subsubsection{Chronoamperometric measurements on $\mathrm{ZnO} / \mathrm{Cu}$ modified electrode in the presence of nitrate.}

Figure 9 (a) illustrates the current versus time transients at a cathodic potential of $-0.68 \mathrm{~V} /$ $\mathrm{SCE}$, onto $\mathrm{ZnO} / \mathrm{Cu}$ electrode in $10 \mathrm{mM}$ of nitrate ions. This applied potential corresponds to the maximum peak for nitrate reduction (Fig.6.e). It is verified that, the variation of current $i$ versus $\mathrm{t}^{-1 / 2}$ is linear with a correlation coefficient of 0.9984 (Fig. 9(b)). 
From the slope of the line $\mathrm{i}=\mathrm{f}\left(\mathrm{t}^{-1 / 2}\right)($ Fig.9 (b)) we can estimate the total number of electrons transferred during the reaction of nitrate reduction using the Cottrell equation (eq.1).

$\mathrm{i}=$ n.F.A.D ${ }^{1 / 2} \cdot \mathrm{C}_{\mathrm{NO} 3}{ }^{-} \cdot \pi^{-1 / 2} \cdot \mathrm{t}^{-1 / 2}$

where $\mathrm{C}$ is the bulk concentration $\left(\mathrm{mol} . \mathrm{cm}^{-3}\right.$ ), $\mathrm{D}$ the diffusion coefficient, $\mathrm{n}$ the number of electron transferred, F the Faraday constant, A the electrode area, i is the current density controlled by the diffusion of $\mathrm{NO}_{3}^{-}$ions from the bulk solution to the electrode/solution interface.

To a concentration $\mathrm{C}\left(\mathrm{NO}_{3}^{-}\right)=0.01 \mathrm{M}, \mathrm{D}=2.10^{-5} \mathrm{~cm}^{2} \cdot \mathrm{s}^{-1}[5], \mathrm{n}$ is equal to $7.901(\mathrm{n}=8)$ corresponding to the number of electrons exchanged in the reaction in accordance with nitrate reduction into ammonia (eq. 2).

$\mathrm{NO}_{3}^{-}+9 \mathrm{H}^{+}+8 e^{-} \rightarrow \mathrm{NH}_{3}+3 \mathrm{H}_{2} \mathrm{O}$

The one step reduction reaction was indicative of rapid $\mathrm{NO}_{3}{ }^{-}$reduction process occurring at the $\mathrm{ZnO} / \mathrm{Cu}$ modified electrode. These results indicate that the reaction proceeds in one step and might be used for ammonia synthesis, a useful product from the industrial point of view.

\subsubsection{Effect of sweep rate}

Figure 10(a) shows the $\mathrm{CV}$ responses of $\mathrm{ZnO} / \mathrm{Cu}$ electrode at different scan rates $(8,20,40$, $60,100$ and $200 \mathrm{mV} / \mathrm{s})$. We can see that the nitrate reduction current increases with the increase of sweep rate and was proportional to the square root sweep rate $($ Fig. 10(b)), implying that the reduction process is diffusion controlled

\section{Conclusion}

The development of specific analytical methods for the detection and destruction of nitrate is of great importance to limit pollution of the natural environment.

In this study, the reduction of nitrate ions on copper electrodes modified by electrodeposition of $\mathrm{ZnO}$ thin films was investigated. The influence of both electrodeposition potential and time on the morphology and structure of $\mathrm{ZnO}$ was studied.

The obtained results showed that, these electrodeposition parameters have a great influence on the structure and morphology of the deposit. The structural analysis of $\mathrm{ZnO}$ obtained at $-1 \mathrm{~V}$ versus SCE for 20min, by XRD shows a polycrystalline structure with a preferential 
orientation along the $\mathrm{c}$ axis perpendicular to the substrate. SEM characterization shows a $\mathrm{ZnO}$ deposit in the form of flowers oriented on the substrate surface.

The results of the electrocatalytic study have shown that the copper electrode modified by $\mathrm{ZnO}$ thin films, at $-1 \mathrm{~V}$ for 20 min electrodeposition time exhibits excellent electrocatalytic activity towards the reduction of nitrate ions. The results are reproducible over a nitrate concentration range of $[0.03 \mathrm{mM}$ to $10 \mathrm{mM}]$. The number of electrons exchanged in the nitrate reduction reaction was determined by chronoamperometry study which is equal to 8 . These results indicate that the reaction proceeds in one step and leads to ammonia a useful product from the industrial point of view. We can conclude that $\mathrm{ZnO} / \mathrm{Cu}$ electrode might be used for ammonia synthesis as well as $\mathrm{NO}_{3}{ }^{-}$detection.

\section{References}

[1] Kim YH, Hwang ED, Shin WS, Choi JH, Ha TW, Choi SJ. Treatments of stainless steel wastewater containing a high concentration of nitrate using reverse osmosis and nanomembranes. Desalination 2007; 202: 286-292.

[2] Elmidaoui A, Elhannouni F, Sahli M, Chay L, Elabbassi H, Hafsi M, Largeteau D. Pollution of nitrate in Moroccan ground water: removal by electrodialysis. Desalination 2001; 136: 325-332.

[3] Molinari R, Argurio P, Romeo L. Studies on interactions between membranes (RO and NF) and pollutants $\left(\mathrm{SiO}_{2}, \mathrm{NO}_{3}{ }^{-}, \mathrm{Mn}^{++}\right.$and humic acid) in water. Desalination 2001; 138: 271-281.

[4] Aslan I, Turkman AE. Combined biological removal of nitrate and pesticides using wheat straw as substrates Process Biochem 2005; 40: 935-943.

[5] Reyter D, Chamoulaud G, Bélanger D, Roué L. Electrocatalytic reduction of nitrate on copper electrodes prepared by high-energy ball milling. J Electroanal Chem 2006; 596: 13-24. [6] Durivault L, Brylev O, Reyter D, Sarrazin M, Bélanger D, Roué L. Cu-Ni materials prepared by mechanical milling: Their properties and electrocatalytic activity towards nitrate reduction in alkaline medium, J Alloys Compd 2007; 432: 323.

[7] Shimazu K, Goto R, Tada K. Electrochemical reduction of nitrate ions on tin-modified platinum and palladium electrodes. Chem Lett 2002; 31: 204-205.

[8] Peel JW, Reddy KJ, Sullivan BP, Bowen JM. Electrocatalytic reduction of nitrate in Water. Water Res 2003; 37: 2512-2519.

[9] Santos L A L, Denier LJ, Varela H. The effect of ultra-low proton concentration on the electrocatalytic reduction of nitrate over platinum. Catal. Commun 2008; 9: 269-272. 
[10] Taguchi S, Feliu J M, Electrochemical reduction of nitrate on Pt (S) [n (llll $\left.\begin{array}{lll}1 & 1 & 1\end{array}\right) \times\left(\begin{array}{lll}1 & 1 & 1\end{array}\right)$ ] electrodes in perchloric acid solution. Electrochim Acta 2007; 52: 6023-6033.

[11] Groot M T, Koper M T. The influence of nitrate concentration and acidity on the electrocatalytic reduction of nitrate on platinum. J Electroanal Chem 2004; 562: 81.

[12] Taguchi S, Feliu JM. Kinetic study of nitrate reduction on Pt ( 1110$)$ electrode in perchloric acid solution. Electrochim Acta 2008; 53: 3626-3634.

[13] Keita B, Abdeljalil E, Nadjo L, Contant R, Belgiche R. First examples of efficient participation of selected metal-ion-substituted heteropolyanions in electrocatalytic nitrate reduction. Electrochem Commun 2001; 3: 56-62.

[14] Reyter D, Belanger D, Roue L. Study of the electroreduction of nitrate on copper in alkaline solution. Electrochimica Acta 2008; 53: 5977-5984.

[15] Bouzek Paidar K, Sadilkova M A, Bergmann H. Electrochemical reduction of nitrate in weakly alkaline solutions. Journal of Applied Electrochemistry 2001; 31: 1185.

[16] Aouina N, Cachet H, Debiemme-Chouvy C, Mai Tran $\mathrm{T} T$. Insight into the electroreduction of nitrate ions at a copper electrode, in neutral solution, after determination of their diffusion coefficient by electrochemical impedance spectroscopy. Electrochim. Acta 2010; 55: 7341-7345.

[17] Pérez-Gallent E, Marta C, Katsounaros I, Marc T, Koper M. .Electrocatalytic reduction of Nitrate on Copper single crystals in acidic and alkaline solutions. Electrochimica Acta 2017; 22: 777-84.

[18] Newbry J E, de Haddad MPL. Amperometric determination of nitrite by oxidation at a glassy carbon electrode. Analyst 1985; 110: 81-82.

[19] Chamdi AY, Fogg AG. Oxidative flow injection amperometric determination of nitrite at an electrochemically pre-treated glassy carbon electrode. Analyst 1998; 113: 1723-1727.

[20] Barisci J N, Wallace GG. Development of an improved on-line chromatographic monitor with new methods for environmental and process control. Analytica Chimica Acta 1995; 310: 79-92.

[21] Kalcher K, Kauffmann JM, Wang J, Svancara I, Vytras K, Neuhold C and al. Sensors based on carbon paste in electrochemical analysis: a review with particular emphasis on the period 1990-1993. Electroanalysis 1995; 7: 5-22.

[22] Svancara I, Vytras K, Zima J, Barek J. Carbon paste electrodes in modern electroanalysis (a review). Crit Rev Anal Chem 2001; 31: 311-345. 
[23] Hamam A, Oukil D, Hammache H, Makhloufi L, Saidani B. Polypyrrole coated cellulosic substrate modified by copper oxide as electrode for nitrate electroreduction, Surf Rev and Lett, 2015; 22(5): 1550065.

[24] Ait Ahmed N, Hammache H, Makhloufi L, Sam S, Keffous A, Gabouze N. Effect of electrodeposition duration on the morphological and structural modification of the flower-like nanostructured ZnO. Vacuum 2015; 120: 100-106.

[25] Ait Ahmed N, Eyraud M, Hammache H, Vacandio F, Sam S, Gabouze N and al. New insight into the mechanism of cathodic electrodeposition of zinc oxide thin films onto vitreous carbon. Electrochim Acta 2013; 94: 238- 244.

[26] Ait Ahmed N, Fortas G, Hammache H, Sam S, Keffous A, Manseri A and al. Structural and morphological study of $\mathrm{ZnO}$ thin films electrodeposited on n-type silicon. Appl Surf Sci 2010; 256: 7442-7445.

[27] Pearton SJ, Norton DP, Ip K, Heo YW, Steiner T. Recent advances in processing of ZnO. J Vac Sci Technol B 2004; 22: 932-948.

[28] Wang Y, Yang J, Jia H, Yu M, Jin H. Self-assembled urchin-like ZnO nanostructures fabricated by electrodeposition-hydrothermal method. J of Alloys and Compounds 2016; 665: 62-68.

[29] Hasnat MA, Amirul Islam M, Borhanuddin SM, Ullah Chowdhury MR, Machida M. Influence of $\mathrm{Rh}$ on electrocatalytic reduction of $\mathrm{NO}_{3}^{-}$and $\mathrm{NO}_{2}^{-}$over $\mathrm{Pt}$ and $\mathrm{Pd}$ films, $\mathrm{J}$ of Molecular Catalysis A: Chemical 2010; 317: 61-67.

[30] Hasnat M A, Ahamad N, Nizam Uddin S M. Silver modified platinum surface $/ \mathrm{H}^{+}$ conducting Nafion membrane for cathodic reduction of nitrate ions. Appl Surf Sci 2012; 258: 3309-3314.

[31] Zhang X, Wang J, Wang Z, Wang Sh. Electrocatalytic reduction of nitrate at polypyrrole modified electrode. Synthetic Metals 2005; 155: 95-99 


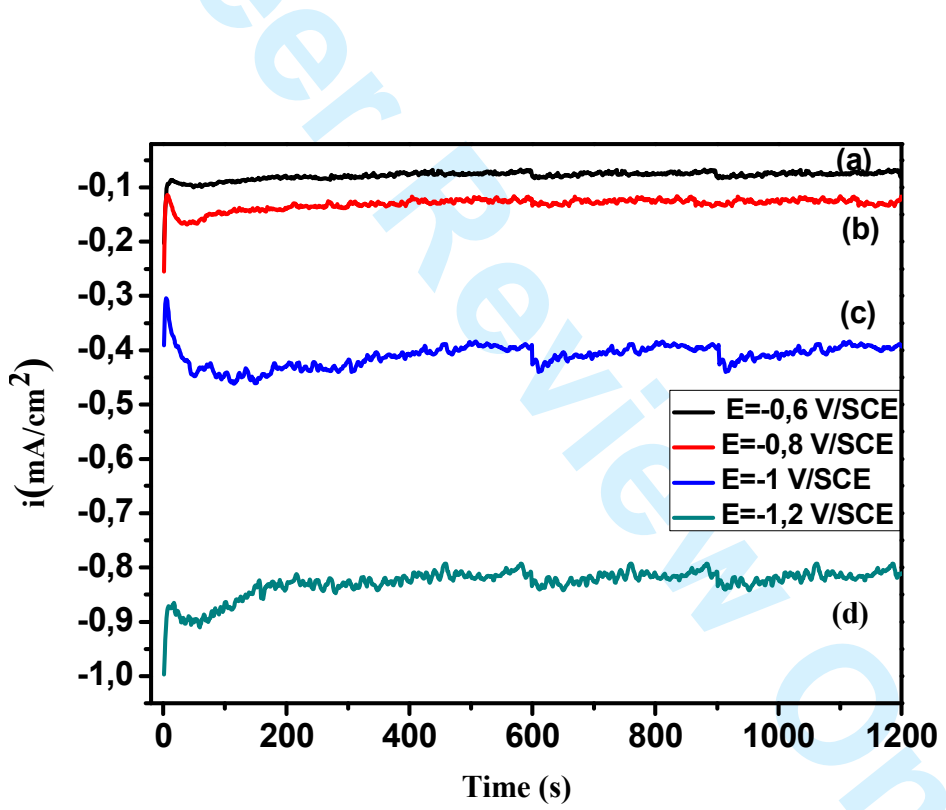

Fig.1:Cyclic voltammogram of $5 \mathrm{mM} \mathrm{Zn}\left(\mathrm{NO}_{3}\right)_{2}+0.1 \mathrm{M} \mathrm{KNO}_{3}$ solutions recorded using $\mathrm{Cu}$ electrode, $\mathrm{pH}=6.8, \mathrm{~T}=70^{\circ} \mathrm{C}, \mathrm{V}_{\mathrm{b}}=8 \mathrm{mV} / \mathrm{s}$.

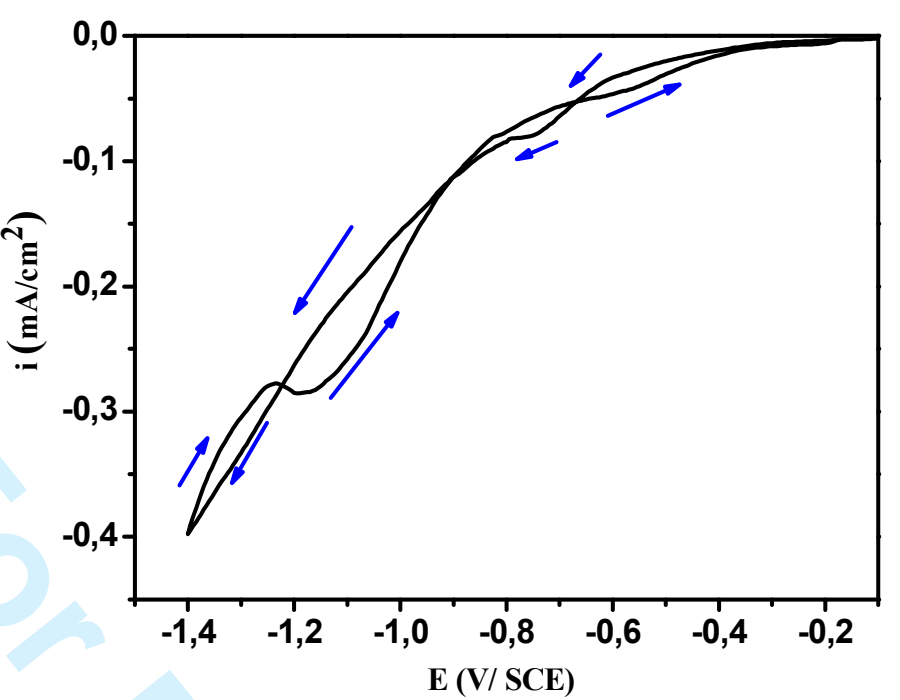

Fig.2: Chronoamperometric response of $\mathrm{Cu}$ electrode in solution containing:[ $\left[\mathrm{Zn}\left(\mathrm{NO}_{3}\right)_{2}\right]=5 \mathrm{mM}$ and $\left[\mathrm{KNO}_{3}\right]=0.1 \mathrm{M}$ at different potentials (a) -0.6 ; (b) -0.8 ; (c) -1 and (d) $-1.2 \mathrm{~V} / \mathrm{SCE}$. $\mathrm{pH}=6.8, \mathrm{~T}=70^{\circ} \mathrm{C}$, $\mathrm{V}_{\mathrm{b}}=8 \mathrm{mV} / \mathrm{s}$. 

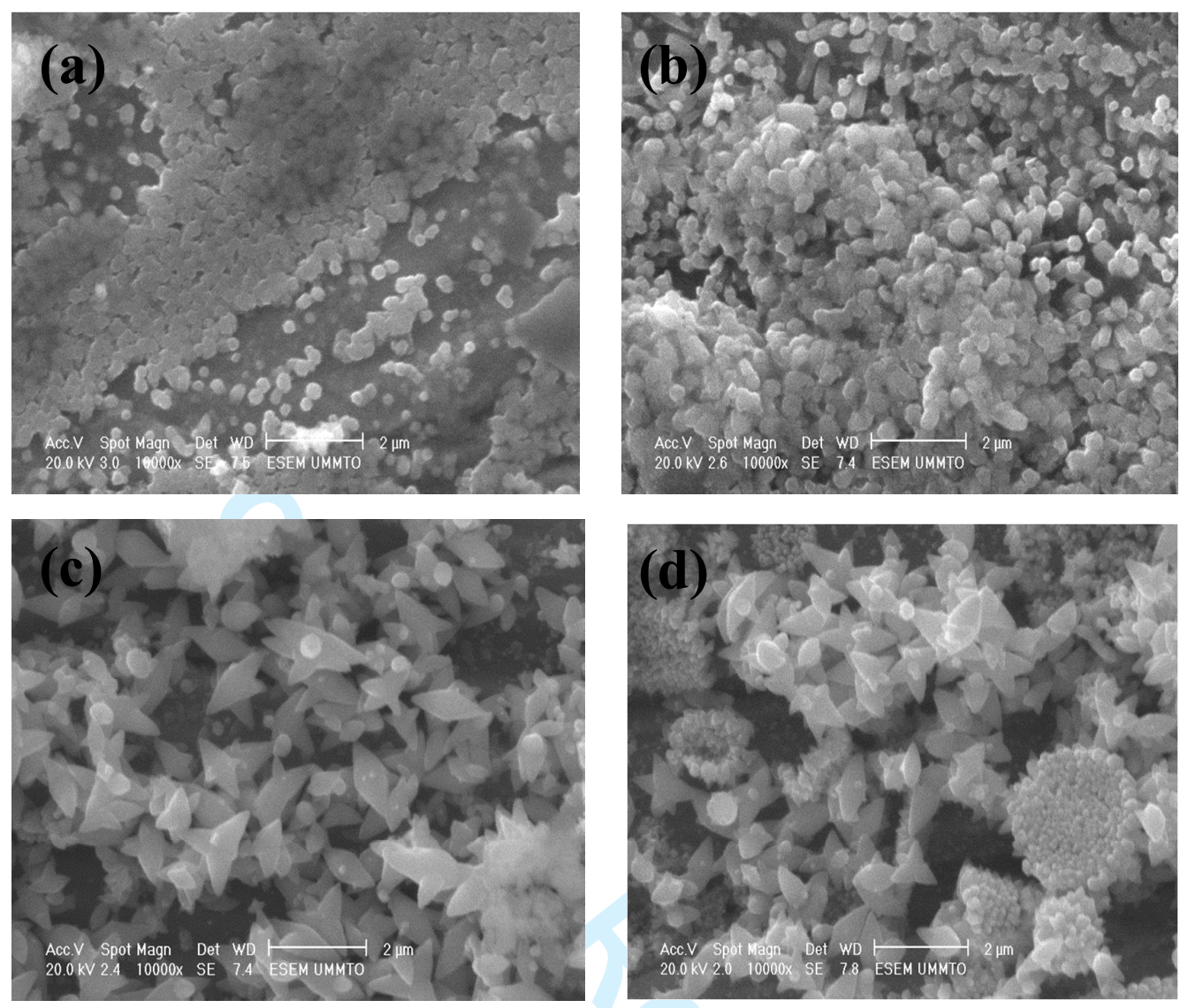

Fig.3: SEM images of $\mathrm{ZnO}$ thin films obtained at different deposition voltages: (a): $-0.6 \mathrm{~V}$, (b): $-0.8 \mathrm{~V}$, (c): $-1 \mathrm{~V}$ and (d): $-1.2 \mathrm{~V}$.

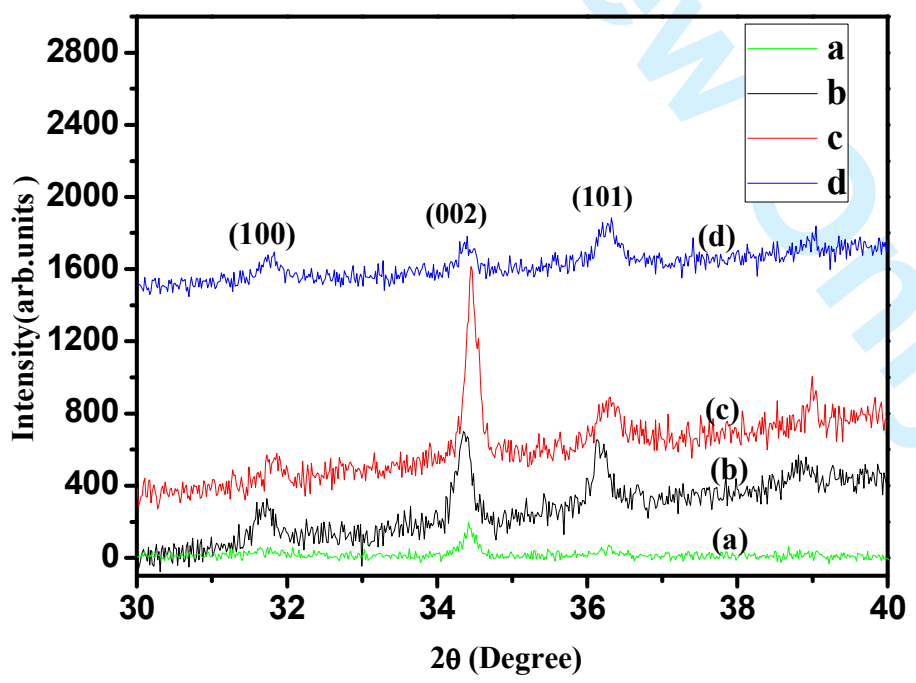

Fig.4: XRD patterns of $\mathrm{ZnO}$ thin films obtained at different deposition voltages: (a): $-0.6 \mathrm{~V}$, (b): $-0.8 \mathrm{~V}$, (c):-1V and (d): $-1.2 \mathrm{~V}$. 


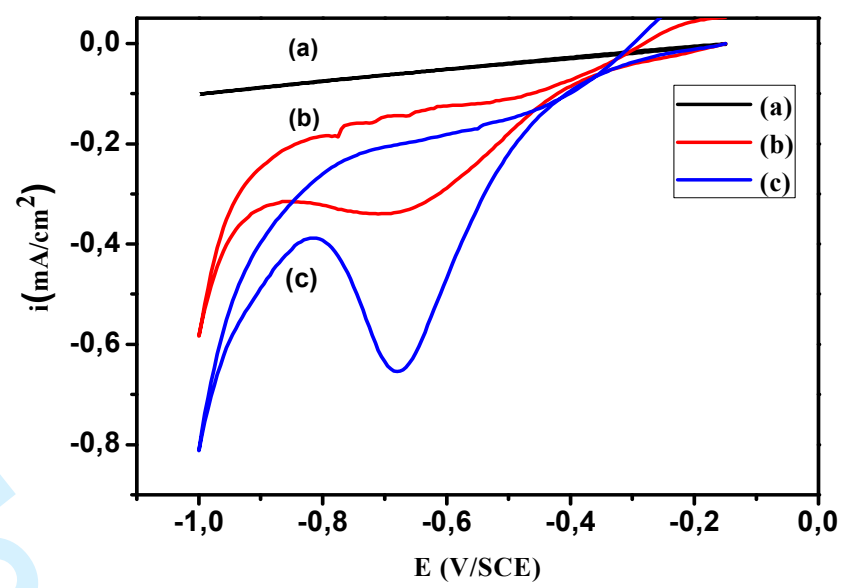

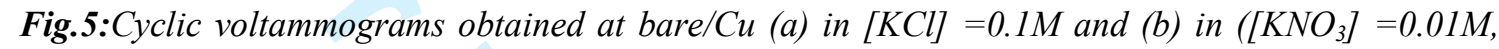
$p H=6.9)$, (c) $\mathrm{ZnO} / \mathrm{Cu}$ deposited at $\left[E=-1 \mathrm{~V}, t=20 \mathrm{~min}, \mathrm{~T}=70^{\circ} \mathrm{C}, \mathrm{pH}=6.8\right]$ in $\left(\left[\mathrm{KNO}_{3}\right]=0.01 \mathrm{M}\right.$, $p H=6.9), \mathrm{Vb}=8 \mathrm{mV} / \mathrm{s}$.
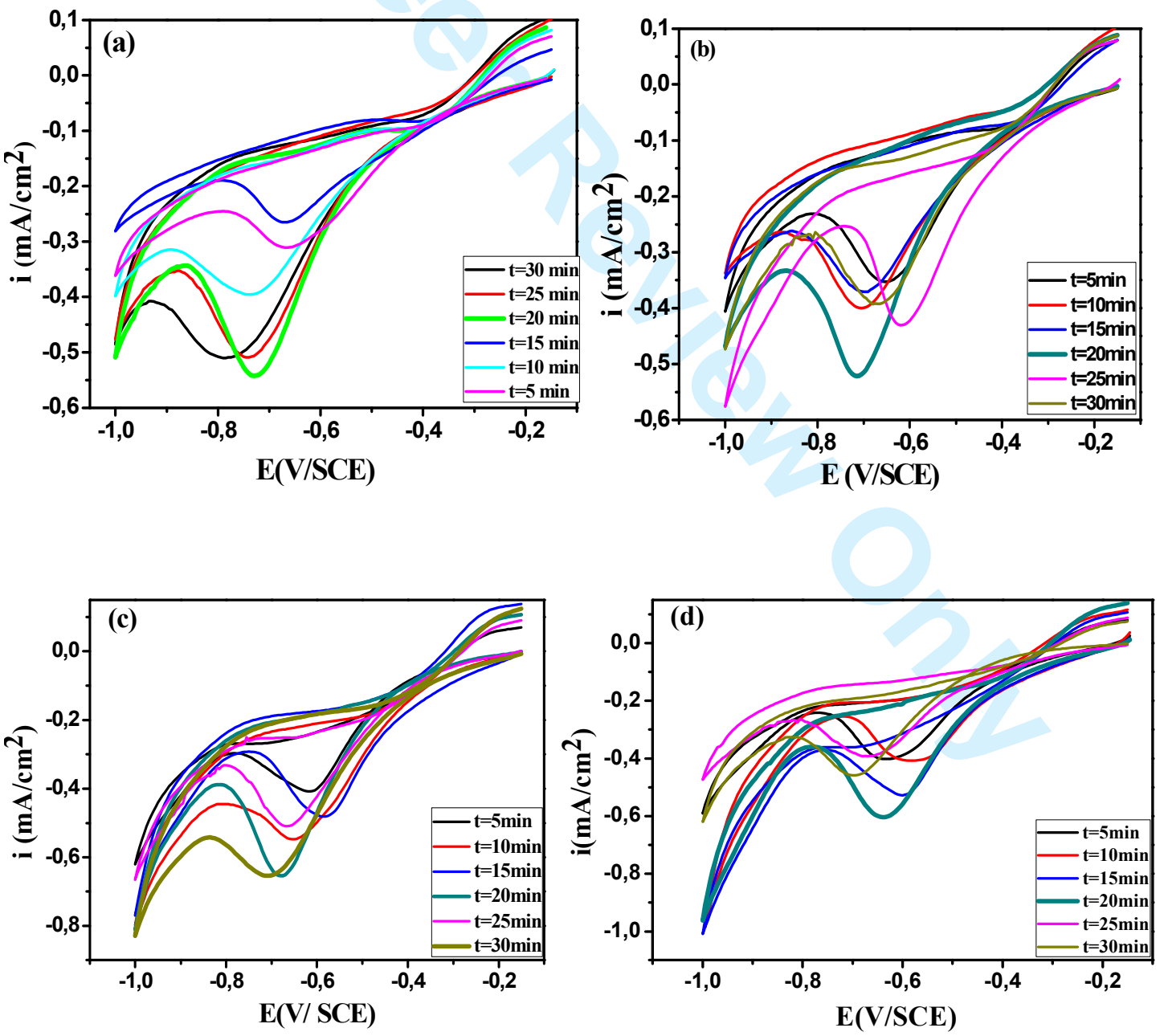

URL: http://mc.manuscriptcentral.com/tdwt 


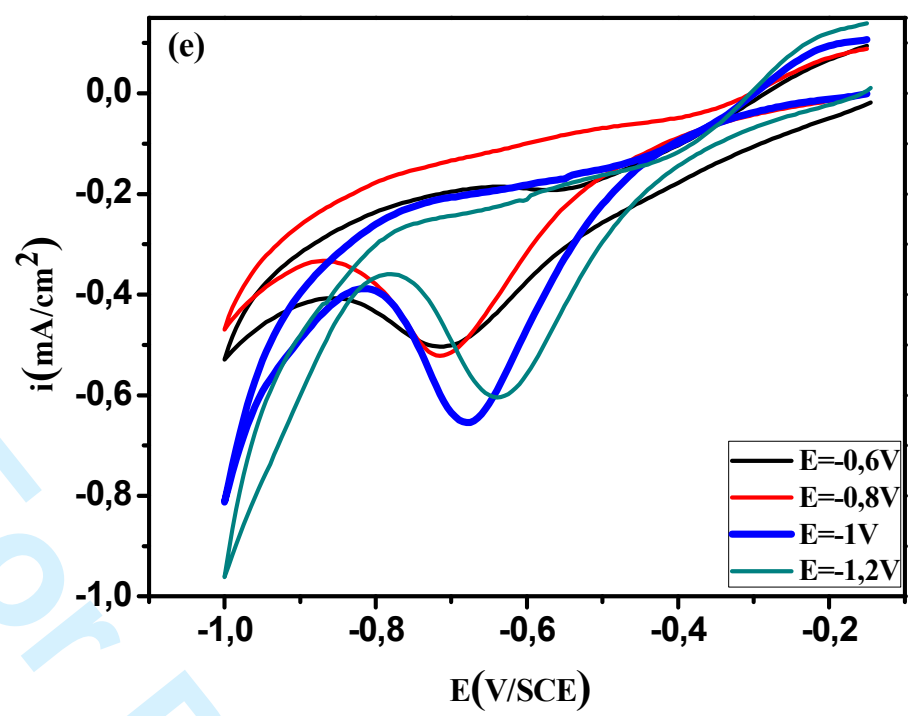

Fig. 6 : Cyclic voltammograms of $\mathrm{ZnO}$ modified $\mathrm{Cu}$ electrode in $0.01 \mathrm{M} \mathrm{KNO}_{3},(\mathrm{pH}=6.9)$ at different potentials ; (a)-0.6, (b)-0.8, (c)-1, (d)-1.2 V/SCE and different deposition times ; 5,10, 15, 20, 25 and $30 \mathrm{~min}, \mathrm{Vb}=8 \mathrm{mV} / \mathrm{s}$. (e): Cyclic voltammograms of $\mathrm{ZnO}$ modified $\mathrm{Cu}$ electrode in $\left(\left[\mathrm{KNO}_{3}\right]=0.01 \mathrm{M}\right.$, $\mathrm{pH}=6.9)$ at different potentials $(\mathrm{E}=-0.6,-0.8,-1,-1.2 \mathrm{~V} / \mathrm{SCE})$ for $20 \mathrm{~min}, \mathrm{Vb}=8 \mathrm{mV} / \mathrm{s}$.

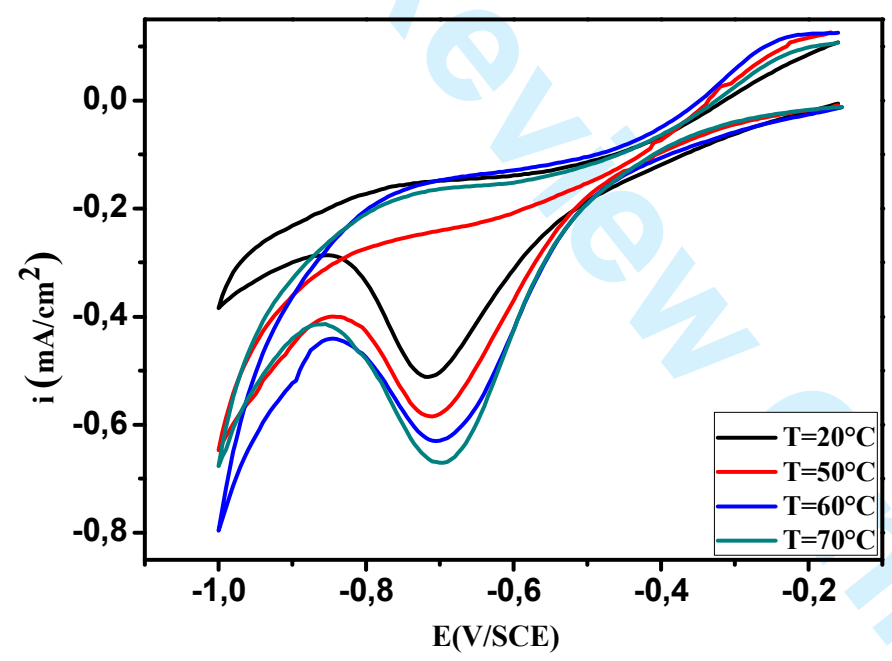

Fig.7: Cyclic voltammograms of $\mathrm{ZnO}$ modified $\mathrm{Cu}$ electrode in $0.01 \mathrm{M} \mathrm{KNO}_{3},(\mathrm{pH}=6.9)$ deposited at $1 \mathrm{~V}$ for $20 \mathrm{~min}$ with different temperatures, $\mathrm{Vb}=8 \mathrm{mV} / \mathrm{s}$. 


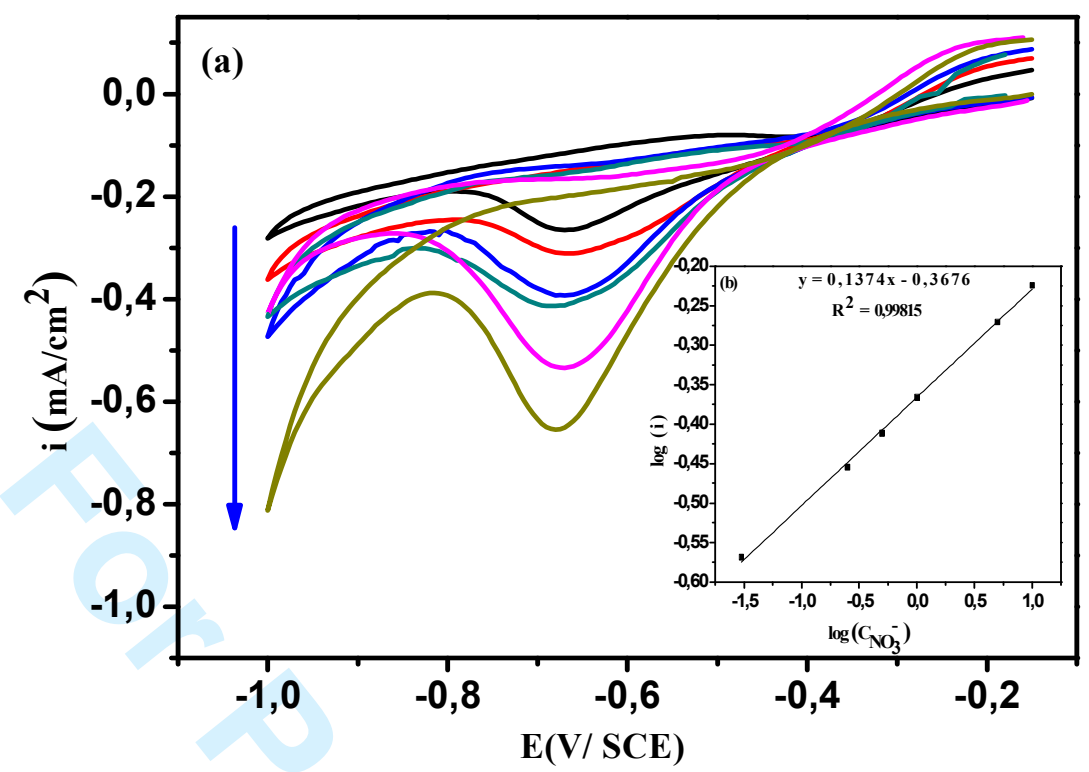

Fig.8: (a) Cyclic voltammograms of $\mathrm{ZnO}$ modified $\mathrm{Cu}$ electrode in $0.01 \mathrm{M} \mathrm{KNO}_{3}$, $(\mathrm{pH}=6.9)$ containing different nitrate concentration:0.03, $0.25,0.5,1,5$ and $10 \mathrm{Mm}$. (b) The insert shows the log of peak current variation withlog of nitrate concentrations. Scan rate $8 \mathrm{mV} \mathrm{s}^{-1}$.
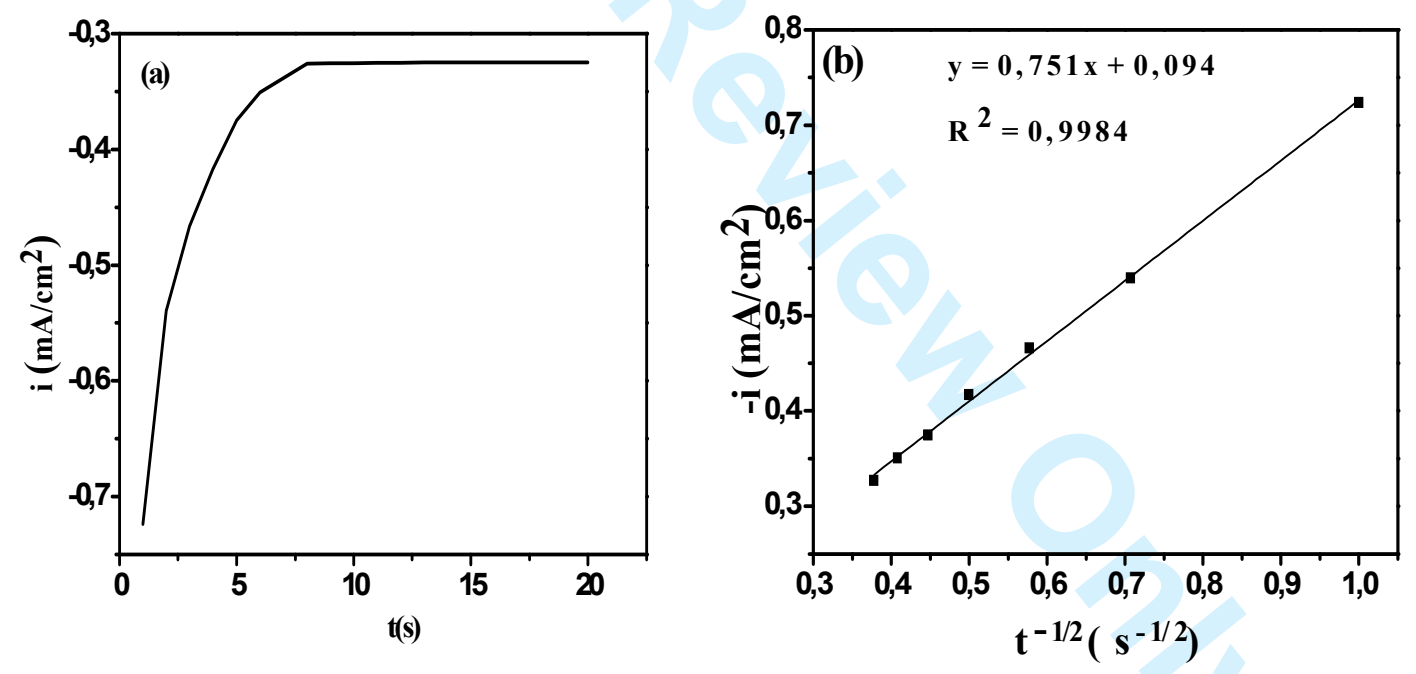

Fig.9: (a) Chronoamperometric response of $\mathrm{ZnO}$ modified $\mathrm{Cu}$ electrode in solution containing $10 \mathrm{mM}$ of nitrate at imposed potential of $-0.68 \mathrm{~V} / \mathrm{SCE}$ (peak potential of Fig. 8). (b) Dependence of the peak current with $\mathrm{t}^{1 / 2}$. 


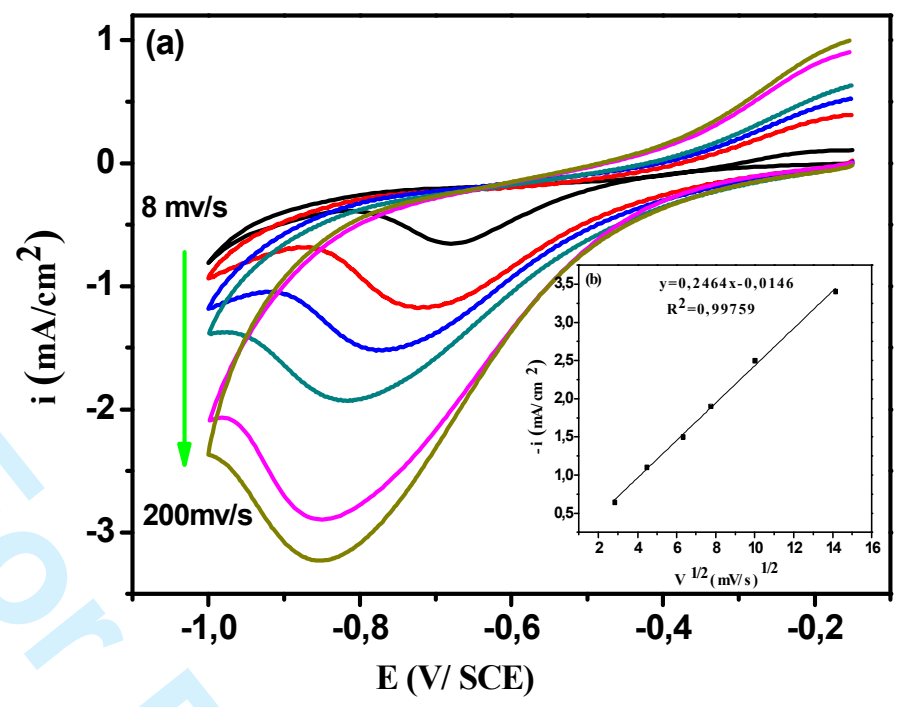

Fig.10 (a): Cyclic voltammetry sweep curve for $\mathrm{ZnO}$ modified $\mathrm{Cu}$ electrode at various scan rates from 8 to $200 \mathrm{mV} / \mathrm{s}$ in $0.01 \mathrm{M} \mathrm{KNO}_{3}(\mathrm{pH}=6.9)$ and (b) the insert figure is the plot between cathodic current versus the square root of the scan rate. 


\section{Figures Captions:}

Fig.1: Cyclic voltammogram of $5 \mathrm{mM} \mathrm{Zn}\left(\mathrm{NO}_{3}\right)_{2}+0.1 \mathrm{M} \mathrm{KNO}_{3}$ solutions recorded using $\mathrm{Cu}$ electrode, $\mathrm{pH}=6.8, \mathrm{~T}=70^{\circ} \mathrm{C}, \mathrm{Vb}=8 \mathrm{mV} / \mathrm{s}$.

Fig.2: Chronoamperometric response of $\mathrm{Cu}$ electrode in solution containing: [ $\mathrm{Zn}$ (NO3)2] $=5 \mathrm{mM}$ and $\left[\mathrm{KNO}_{3}\right]=0.1 \mathrm{M}$ at different potentials (a) -0.6 ; (b) -0.8 ; (c) -1 and (d) $-1.2 \mathrm{~V} / \mathrm{SCE}$. $\mathrm{pH}=6.8, \mathrm{~T}=70^{\circ} \mathrm{C}, \mathrm{Vb}=8 \mathrm{mV} / \mathrm{s}$.

Fig.3: SEM images of $\mathrm{ZnO}$ thin films obtained at different deposition voltages: (A): $-0.6 \mathrm{~V}$, (B): $-0.8 \mathrm{~V},(\mathrm{C}):-1 \mathrm{~V}$ and (D): $-1.2 \mathrm{~V}$.

Fig.4: XRD patterns of $\mathrm{ZnO}$ thin films obtained at different deposition voltages: (a): $-0.6 \mathrm{~V}$, (b): $-0.8 \mathrm{~V},(\mathrm{c}):-1 \mathrm{~V}$ and $(\mathrm{d}):-1.2 \mathrm{~V}$.

Fig.5: Cyclic voltammograms obtained at bare $/ \mathrm{Cu}(\mathrm{a})$ in $[\mathrm{KCl}]=0.1 \mathrm{M}$ and (b) in $\left(\left[\mathrm{KNO}_{3}\right]=\right.$ $0.01 \mathrm{M}, \mathrm{pH}=6.9)$, (c) $\mathrm{ZnO} / \mathrm{Cu}$ deposited at $\left[\mathrm{E}=-1 \mathrm{~V}, \mathrm{t}=20 \mathrm{~min}, \mathrm{~T}=70^{\circ} \mathrm{C}, \mathrm{pH}=6.8\right]$ in $\left(\left[\mathrm{KNO}_{3}\right]\right.$ $=0.01 \mathrm{M}, \mathrm{pH}=6.9), \mathrm{Vb}=8 \mathrm{mV} / \mathrm{s}$.

Fig. 6 : Cyclic voltammograms of $\mathrm{ZnO}$ modified $\mathrm{Cu}$ electrode in $0.01 \mathrm{M} \mathrm{KNO}_{3},(\mathrm{pH}=6.9)$ at different potentials ; (a)-0.6, (b)-0.8, (c)-1, (d)-1.2 V/SCE and different deposition times ; 5,10, 15,20, 25 and $30 \mathrm{~min}, \mathrm{Vb}=8 \mathrm{mV} / \mathrm{s}$. (e): Cyclic voltammograms of $\mathrm{ZnO}$ modified $\mathrm{Cu}$ electrode in $\left(\left[\mathrm{KNO}_{3}\right]=0.01 \mathrm{M}, \mathrm{pH}=6.9\right)$ at different potentials $(\mathrm{E}=-0.6,-0.8,-1,-1.2 \mathrm{~V} / \mathrm{SCE})$ for $20 \mathrm{~min}, \mathrm{Vb}=8 \mathrm{mV} / \mathrm{s}$.

Fig.7: Cyclic voltammograms of $\mathrm{ZnO}$ modified $\mathrm{Cu}$ electrode in $0.01 \mathrm{M} \mathrm{KNO}_{3},(\mathrm{pH}=6.9)$ deposited at $-1 \mathrm{~V}$ for $20 \mathrm{~min}$ at different temperatures, $\mathrm{Vb}=8 \mathrm{mV} / \mathrm{s}$.

Fig.8: (a) Cyclic voltammograms of $\mathrm{ZnO}$ modified $\mathrm{Cu}$ electrode in $0.01 \mathrm{M} \mathrm{KNO}_{3},(\mathrm{pH}=6.9)$ containing different nitrate concentration:0.03, 0.25, 0.5, 1, 5 and $10 \mathrm{mM}$. (b)The insert shows the $\log$ of peak current variation with $\log$ of nitrate concentrations. Scan rate $8 \mathrm{mV} \mathrm{s}^{-1}$.

Fig.9: (a) Chronoamperometric response of $\mathrm{ZnO}$ modified $\mathrm{Cu}$ electrode in solution containing $10 \mathrm{mM}$ of nitrate at imposed potential of $-0.68 \mathrm{~V} / \mathrm{SCE}$ (peak potential of Fig. 9). (b) Dependence of the peak current with $\mathrm{t}^{1 / 2}$.

Fig.10 (a): Cyclic voltammetry sweep curve for $\mathrm{ZnO}$ modified $\mathrm{Cu}$ electrode at various scan rates from 8 to $200 \mathrm{mV} / \mathrm{s}$ in $0.01 \mathrm{M} \mathrm{KNO}_{3}(\mathrm{pH}=6.9)$ and (b) the insert figure is the plot between cathodic current versus the square root of the scan rate. 